\title{
Time Course Changes in Selected Biochemical Stress Indices in Broilers Exposed to Short-term Noise
}

\author{
Iveta Bedáňová, Petr Chloupek, Petra Vošmerová, Jan Chloupek, Vladimír Večerek \\ Faculty of Veterinary Hygiene and Ecology, University of Veterinary and Pharmaceutical Sciences in Brno, \\ Czech Republic \\ Received September 17, 2009 \\ Accepted May 13, 2010
}

\begin{abstract}
Time course changes in selected biochemical stress indices (corticosterone, triglycerides, glucose, cholesterol) following short-term noise exposure at $100 \mathrm{~dB}$ for 28 min were studied in broilers aged 42 days. Corticosterone concentrations were found to increase during the first 10 min of noise exposure and to differ significantly from the control (background sound $-50 \mathrm{~dB}$ ) at Time $10 \mathrm{~min}$ and $14 \mathrm{~min}$, then decreased continually and at $28 \mathrm{~min}$ returned to the initial prestress value. Triglyceride concentrations increased in broilers exposed to $100 \mathrm{~dB}$ noise during the first $12 \mathrm{~min}$ with a significant difference from the control at $12 \mathrm{~min}$ and $14 \mathrm{~min}$. Glucose concentrations were higher due to $100 \mathrm{~dB}$ noise exposure for almost the entire period monitored, with significant differences between $100 \mathrm{~dB}$ and control broilers at $6 \mathrm{~min}$ and from $10 \mathrm{~min}$ to 14 min. Similarly as for the corticosterone concentration, a drop in triglycerides and glucose concentrations was seen approximately from Time $14 \mathrm{~min}$ and a return to the pre-stress value at $28 \mathrm{~min}$. The cholesterol concentrations showed various temporal patterns with no significant difference between $100 \mathrm{~dB}$ and control broilers in this experiment. The pattern of response found in the study indicates that $100 \mathrm{~dB}$ noise represents a stress factor in broilers, however, there is the ability of broilers to adapt to an increased level of noise at this intensity after the first 14 min of exposure. The findings obtained in the study may contribute to expanding detailed knowledge of physiological stress responses to this specific noise stimulus in poultry, and could thereby be used to improve the welfare of broilers in intensive housing systems.
\end{abstract}

Corticosterone, glucose, triglycerides, sound, stress, welfare

The chronology of physiological responses that constitute stress in poultry, in particular stress responses following direct mediation of the adrenal glands by exogenous administration of adrenocorticotropic hormone (ACTH) and exogenous administration of steroid hormones (e.g. corticosterone, cortisone, cortisol, etc.), has been studied in various models. The physiological stress responses that occur most frequently in broilers following ACTH treatment include elevation of plasma corticosterone (Edens and Siegel 1975; Beuving and Vonder 1986; Beuving et al. 1989), elevation of plasma glucose (Siegel and Beane 1961; Siegel 1962ab), and elevation of plasma cholesterol (Siegel and Siegel 1966; Siegel 1968). Puvadolpirod and Thaxton (2000a) proposed a model to study stress responses in chickens that involved continuous administration of ACTH by subcutaneously implanted mini-osmotic pumps. They described stress based on increased circulating levels of corticosterone, glucose, triglycerides and cholesterol and an increased heterophil/lymphocyte ratio. Puvadolpirod and Thaxton (2000b) describe the temporal patterns of stress responses following continuous infusion of ACTH. Their results indicate that plasma corticosterone was elevated by $2 \mathrm{~h}$ and plasma glucose was elevated by $12 \mathrm{~h}$. According to Madis on et al. (2008), injection of corticotropin releasing hormone induced a significant increase in corticosterone levels beginning at $15 \mathrm{~min}$ post-injection through 2 $\mathrm{h}$ in chickens.

Although the temporal patterns of stress responses following direct mediation of the adrenal glands in poultry species have been studied extensively, time course changes in

Address for correspondence:

Doc. RNDr. Iveta Bedáňová, Ph.D.

Department of Veterinary Public Health and Toxicology

Faculty of Veterinary Hygiene and Ecology

University of Veterinary and Pharmaceutical Sciences in Brno

Palackého 1-3, 61242 Brno, Czech Republic

Tel.: +420 541562775

Fax: +420 541562790

E-mail: bedanovai@vfu.cz

http://www.vfu.cz/acta-vet/actavet.htm 
biochemical stress indices caused by acute noise exposure in broilers have not previously been studied. It has been documented that noise represents a potential stressor to farm animals (e.g. De la Fuente et al.2007; Kanitz et al.2005; Otten et al.2004; Weeks 2008), but noise as a stress factor in fowls has not yet been sufficiently investigated. According to Campo et al. (2005) noise seems to affect adversely the productive performance and behaviour of the birds. Stadelman (1958a) reported violent behavioural response in young chickens to intermittent sound exposure at 100-118 dB. Sound intensities of 115 $\mathrm{dB}$ were effective in interrupting brooding in hens (Stadelman 1958b). A significant negative effect of acute noise exposure at $80 \mathrm{~dB}$ and $100 \mathrm{~dB}$ on stressfulness in broilers was described by Chloupek et al. (2009), who found a significant increase in corticosterone and cholesterol levels after 10 min of noise exposure. In contrast, $\mathrm{McF}$ arlane and Curtis (1989) reported that plasma corticosterone was unaffected by continuous noise at $95 \mathrm{~dB}$ in female chicks on trial Day 7.

The literature indicates that more detailed information and temporal patterns of physiological stress response to noise stimulus in poultry are missing. The purpose of the present study was to investigate time course changes in selected biochemical stress indices (corticosterone, triglycerides, cholesterol, glucose) in broilers following acute noise exposure at $100 \mathrm{~dB}$ in order to define more precisely the response to this specific stress factor.

\section{Materials and Methods}

Animals and their treatment

Time course changes in selected biochemical stress indices caused by noise exposure were monitored in a group of ROSS 308 broiler chickens aged 42 days. From the first day after hatching, a total number of 360 broilers were housed in deep litter in an experimental barn with controlled light, heating, and feeding patterns according to standard breeding requirements for meat hybrid poultry. The ambient barn temperature was gradually decreased from $30 \pm 1{ }^{\circ} \mathrm{C}$ on Day 1 to $20 \pm 1{ }^{\circ} \mathrm{C}$ on the last day of fattening (Day 42). Depending on the temperature, relative humidity levels ranged between $25 \%$ and $65 \%$. When the broilers reached 42 days, 15 broilers were selected at random for testing. The selected broilers were individually captured and transferred by hand to the adjacent test room, where they were left undisturbed for $30 \mathrm{~min}$ in order to ensure that the results would not be affected by the transfer. Then the broilers were exposed to a continuous $100 \mathrm{~dB}$ of noise (a mixture of various sounds recorded in commercial broiler housing, sounds of bird vocalization and ventilation fans were predominant) for 28 min. A Boschmann G-9633 S (BM Boschmann, J) speaker was hung in the test room to broadcast the sounds. The noise intensity was measured using a GSH 8922 digital sound meter (Greisinger, D). During the noise exposure, blood samples $(3 \mathrm{ml})$ for biochemical examination were taken from the vena basilica in broilers at 2-min intervals (sampling times: Time $0 \mathrm{~min}, 2 \mathrm{~min}, 4 \mathrm{~min}$...28 min). Each bird of the group was sampled only once and then was removed from the experiment. After the test was finished, 15 more broilers were selected randomly for the control group and transferred into the test room. They also were left undisturbed for $30 \mathrm{~min}$, then kept there without elevated noise exposure (the background sound level was $50 \mathrm{~dB}$ ) and sampled in the same way as the previous test broilers (blood samples were taken from the vena basilica at 2 -min intervals). This cycle of $2 \times 15$ samples was repeated 10 times, meaning that of total of $10 \times 15$ samples of test broilers and $10 \times 15$ samples of control broilers was obtained. These samples represent the time course changes in monitored biochemical indices at 2-min intervals during the experiment (with or without elevated noise). Blood samples were collected within $3 \mathrm{~min}$ of capture in order to ensure that the levels of the monitored indicators were not affected by stress induced from pre-sampling handling (Voslarova et al. 2008). The sex ratio of the broilers in the experiment was $50 \%$ to $50 \%$. The effect of gender was not, however, monitored during the experiment, as preliminary tests have shown this not to be statistically significant.

Biochemical examination

The heparinized blood was centrifuged at $837 \times g$ for $10 \mathrm{~min}$ and plasma samples were stored deep-frozen $\left(-80^{\circ} \mathrm{C}\right)$ in Eppendorf test-tubes until analyses were performed (within one week). Selected plasma biochemical indices: glucose, cholesterol and triglycerides were measured by a Cobas EMira biochemical analyser using commercial test kits (BioVendor - Laboratorni medicina a.s., CZ). The plasma corticosterone concentration was measured using a commercial Corticosterone EIA Kit (Cayman Chemical, USA).

\section{Statistics}

The results were analysed using commercial statistical package Unistat 5.1. (Unistat Ltd., GB). All data were subjected to the general linear model (GLM) analysis of variance (Zar 1999). One-way ANOVA was used to test for significant differences between means for treatment effects $(100 \mathrm{~dB}$ noise and control $)$ at each of the sampling times. 


\section{Results and Discussion}

Results concerning the effects of exposure to $100 \mathrm{~dB}$ noise for $30 \mathrm{~min}$ on monitored biochemical stress indices (corticosterone, triglycerides, cholesterol, glucose) are presented in Fig. 1 (Fig. 1a-1d, respectively).
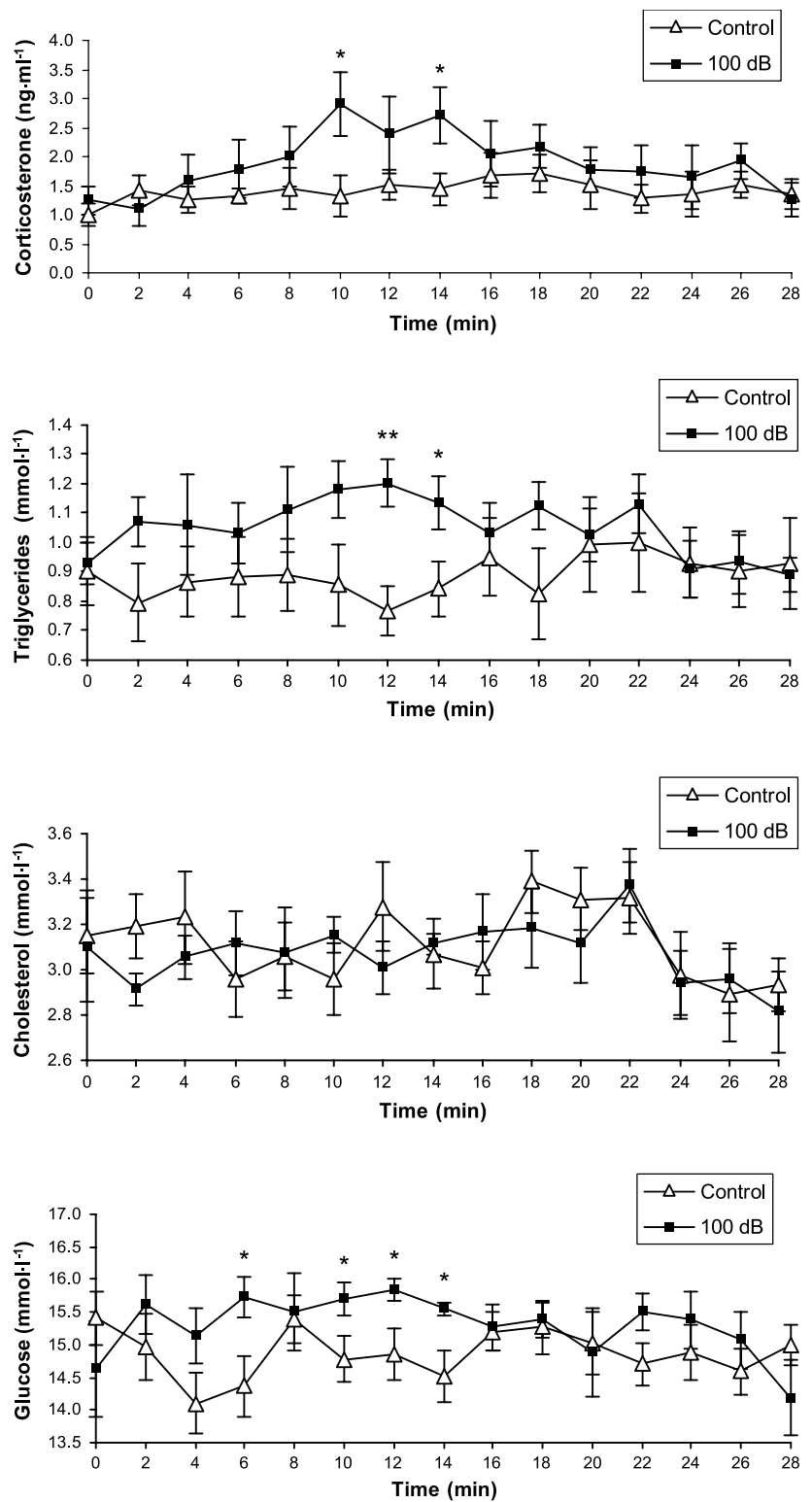

Fig. 1. Time course changes in monitored stress indices (a) corticosterone, b) triglycerides, c) cholesterol, d) glucose) in broilers exposed to $100 \mathrm{~dB}$ noise and control broilers without noise exposure. Vertical bars represent SEM for each mean. * $p<0.05, * * p<0.01$. 
As shown in Fig. 1a, corticosterone concentrations in broilers exposed to $100 \mathrm{~dB}$ noise were found to increase during the first $10 \mathrm{~min}$ and differ significantly from the control at Time $10 \mathrm{~min}$ and $14 \mathrm{~min}(p=0.028$ and $p=0.033$, respectively). From Time $14 \mathrm{~min}$, corticosterone concentrations continually decreased and at $28 \mathrm{~min}$ the corticosterone concentration returned to the initial value, which is identical to the control and represents the pre-stress corticosterone concentration in the experiment. Fig. 1b depicts increasing triglycerides concentrations in broilers exposed to $100 \mathrm{~dB}$ noise during the first 12 min with a significant difference from the control at $12 \mathrm{~min}$ and $14 \mathrm{~min}(p=0.002$ and $p=0.041$, respectively). Similarly as for the corticosterone concentration a fall in triglycerides concentrations can be seen here from Time $14 \mathrm{~min}$ and a return to the pre-stress value at $28 \mathrm{~min}$. The cholesterol concentrations in Fig. 1c show various temporal patterns with no significant difference between $100 \mathrm{~dB}$ and control broilers. As shown in Fig. 1d, glucose concentrations were higher in broilers exposed to $100 \mathrm{~dB}$ noise for almost the entire period monitored, with significant differences $(p<0.05)$ between $100 \mathrm{~dB}$ and control broilers at $6 \mathrm{~min}$ and from $10 \mathrm{~min}$ to $14 \mathrm{~min}$. A fall in glucose concentrations can also be seen here approximately from Time $12 \mathrm{~min}$ and a return to the pre-stress value at $28 \mathrm{~min}$.

Our findings demonstrate that noise can be a potential stress factor to broilers, which induces specific changes in some biochemical stress indices even during just a short time exposure. As far as the authors know, temporal patterns of physiological stress responses in the case of acute noise exposure have not yet been studied in poultry. Only the chronology of the stress response following direct mediation of the adrenal glands has been documented by several authors (e.g. Siegel 1995; Puvadolpirod and Thaxton 2000a,b; Madison et al. 2008). The most frequently occurring physiological responses in broilers included increased levels of corticosterone, glucose, triglycerides and cholesterol. Similarly to the above mentioned authors, we also observed a stress response based on an increase in plasma corticosterone, triglycerides and glucose concentrations in broilers following acute noise exposure at $100 \mathrm{~dB}$. The corticosterone concentration reached its highest values from Time $10 \mathrm{~min}$ to $14 \mathrm{~min}$ in $100 \mathrm{~dB}$ broilers in our experiment, then decreased again to the prestress concentration at $28 \mathrm{~min}$. Chloupek et al. (2009) also described a significant increase in the corticosterone level after $10 \mathrm{~min}$ of noise exposure at $80 \mathrm{~dB}$ and $100 \mathrm{~dB}$ in broilers. McFarlane and Curtis (1989), who reported that plasma corticosterone was unaffected by continuous noise at a level of $95 \mathrm{~dB}$ on trial Day 7 in broiler chicks, support our findings regarding a following decrease in corticosterone levels after $14 \mathrm{~min}$ of exposure to the elevated noise in our experiment.

We also found a significant increase in plasma triglycerides and glucose concentrations during the first $12 \mathrm{~min}$ in broilers exposed to $100 \mathrm{~dB}$ noise in our experiment. Similarly to corticosterone concentrations, a subsequent decrease of triglycerides and glucose levels can also be seen here approximately from Time $12 \mathrm{~min}$ and a gradual return to the prestress value at $28 \mathrm{~min}$. This type of response may indicate the ability of broilers to adapt to an increased level of noise at $100 \mathrm{~dB}$ intensity after the first $12 \mathrm{~min}$ of exposure. In contrast to our experiment, Chloupek et al. (2009) did not find any changes in plasma triglycerides and glucose concentrations in broilers exposed to noise at 80 and $100 \mathrm{~dB}$ for $10 \mathrm{~min}$. These authors also described a significant increase in the cholesterol level in broilers following $10 \mathrm{~min}$ of noise exposure at $100 \mathrm{~dB}$, which is in contradiction with our findings, in that cholesterol concentrations showed various temporal patterns with no significant difference between $100 \mathrm{~dB}$ and control broilers for the whole period monitored in our experiment.

In conclusion, the results of this study describe time course changes in corticosterone, triglycerides, glucose and cholesterol concentrations in broilers following acute noise exposure at an intensity of $100 \mathrm{~dB}$, and thereby define more precisely the stress response to this specific noise stimulus. The pattern of response found in the study indicates that 100 $\mathrm{dB}$ noise represents a stress factor in broilers, however, there is the ability of broilers to 
adapt to an increased level of noise at this intensity after the first $14 \mathrm{~min}$ of exposure. The findings obtained may contribute to expanding detailed knowledge of physiological stress responses to noise stimulus in poultry, and could thereby be used to improve the welfare of broilers in intensive housing systems.

\section{Časový průběh změn ve vybraných biochemických ukazatelích stresu u brojlerů vystavených akutnímu hluku}

Časový průběh změn ve vybraných biochemických ukazatelích stresu (kortikosteron, triglyceridy, glukóza, cholesterol) vlivem akutního hluku o intenzitě 100 dB byl sledován u brojlerů ve věku 42 dnů. Během prvních 10 min hlukové expozice se u brojlerů zvyšovala hladina plazmatického kortikosteronu, přičemž významného rozdílu ve srovnání s kontrolní skupinou (zvuky pozadí - $50 \mathrm{~dB}$ ) dosáhla v čase 10 min a 14 min a poté se plynule snižovala, až v čase 28 min dosáhla opět výchozí klidové hodnoty. Hladina triglyceridů se u brojlerů vlivem expozice $100 \mathrm{~dB}$ hluku zvyšovala během prvních $12 \mathrm{~min}$ expozice, přičemž významný rozdíl ve srovnání s kontrolními brojlery byl zjištěn v čase $12 \mathrm{~min}$ a $14 \mathrm{~min}$. Koncentrace plazmatické glukózy u brojlerů vystavených hluku byly ve srovnání s kontrolou vyšší po téměř celou sledovanou dobu, s významnými rozdíly v čase 6 min a v době od 10 min do 14 min. Podobně jako u koncentrace kortikosteronu, také u hladiny triglyceridů a glukózy bylo možno vysledovat pokles přibližně od 14. minuty po začátku hlukové expozice brojlerů a postupný návrat ke klidovým hladinám v čase 28 min. Koncentrace cholesterolu u brojlerů vystavených $100 \mathrm{~dB}$ hluku vykazovala po celou sledovanou dobu značné kolísání s nevýznamnými rozdíly od kontroly. Průběh odpovědi sledovaných biochemických ukazatelů v této studii ukazuje, že ačkoliv hluk o intenzitě 100 $\mathrm{dB}$ představuje pro brojlery stresový faktor, je zde naznačena možnost adaptace brojlerů, ke které dochází přibližně po prvních 14 minutách expozice této intenzitě hluku. Poznatky získané v této studii mohou přispět k rozšíření podrobných znalostí o fyziologické odpovědi drůbeže na stresové zatížení vlivem specifické hladiny hluku a tím i ke zlepšení welfare v intenzivních systémech výkrmu brojlerů.

\section{Acknowledgements}

Supported by the Research Project No MSM6215712402 Veterinary Aspects of Food Safety and Quality.

\section{References}

Beuving G, Jones RB, Blokhius HJ 1989: Adrenocortical and heterophil/lymphocyte responses to challenge in hens showing short or long tonic immobility reactions. Br Poult Sci 30: 175-159

Beuving G, Vonder GMA 1986: Comparison of the adrenal sensitivity to ACTH of laying hens with immobilization and the plasma baseline levels of corticosterone. Gen Comp Endocrinol 62: 353-358

Campo JL, Gil MG, Davila SG 2005: Effects of specific noise and music stimuli on stress and fear levels of laying hens of several breeds. Appl Anim Behav Sci 91: 75-84

De la Fuente J, Diaz MT, Ibanez M, de Chavarri EG 2007: Physiological response of rabbits to heat, cold, noise and mixing in the context of transport. Anim Welf 16: 41-47

Edens FW, Siegel HS 1975: Adrenal responses in high and low ACTH response lines of chicken during acute heat stress. Gen Comp Endocrinol 25: 64-73

Chloupek P, Voslarova E, Chloupek J, Bedanova I, Pistekova V, Vecerek V 2009: Stress in broiler chickens due to acute noise exposure. Acta vet Brno 78: 93-98

Kanitz E, Otten W, Tuchscherer M. 2005: Central and peripheral effects of repeated noise stress on hypothalamicpituitary-adrenocortical axis in pigs. Livest Prod Sci 94: 213-224

Madison FN, Jurkevich A, Kuenzel WJ. 2008: Sex differences in plasma corticosterone release in undisturbed chickens (Gallus gallus) in response to arginine vasotocin and corticotropin releasing hormone. Gen Comp Endocrinol 155: 566-573

McFarlane JM, Curtis SE 1989: Multiple concurrent stressors in chicks 3. Effects on plasma-corticosterone and the heterophil-lymphocyte ratio. Poult Sci 68: 522-527

Otten W, Kanity E, Puppe B, Tuchscherer M, Brussow KP, Nurnberg G, Stabenow B 2004:Acute and long term effects of chronic intermittent noise stress on hypothalamic-pituitary-adrenocortical and sympathoadrenomedullary axis in pigs. Anim Sci 78 (Part 2): 271-283 
Puvadolpirod S, Thaxton JS 2000a: Model of physiological stress in chickens 1. Response parameters. Poult Sci 79: $363-369$

Puvadolpirod S, Thaxton JS 2000b: Model of physiological stress in chickens 3. Temporal Patterns of Response. Poult Sci 79: 377-382

Siegel HS 1962a: Age and sex modification of responses to adrenocorticotropin in young chickens. 1. Changes in adrenal and lymphatic gland weights. Poult Sci 40: 1263-1274

Siegel HS 1962b: Age and sex modification of responses to adrenocorticotropin in young chickens. 2. Changes in adrenal cholesterol and blood constituent levels. Poult Sci 41: 321-334

Siegel HS 1968: Blood cells and chemistry of young chickens during daily ACTH and cortisol administration. Poult Sci 47: 1811-1817

Siegel HS 1995: Stress, strains and resistance. Br Poult Sci 36: 3-22

Siegel HS, Beane WL 1961: Time responses to single intramuscular doses of ACTH in chickens. Poult Sci 40: 216-219

Siegel HS, Siegel PB 1966: Genetic variation in responses to repeated administrations of ACTH and hydrocortisone in immature chickens. Poult Sci 45: 901-912

Stadelman WJ 1958a: Observations with growing chickens on the effects of sounds of varying intensities. Poult Sci 37: 776-779

Stadelman WJ 1958b: The effect of sounds of varying intensity on hatchability of chicken eggs. Poult Sci 37: 166-169

Voslarova E, Chloupek P, Bedanova I, Suchy P, Pistekova V, Vecerek V 2008: The effect of pre-sampling handling time on blood plasma biochemical parameters of broilers. Dtsch Tierarztl Wochenschr 115: 62-65

Weeks CA 2008: A review of welfare in cattle, sheep and pig lairages, with emphasis on stocking rates, ventilation and noise. Anim Welf 17: 275-284

Zar JH 1999: Biostatistical Analysis. Prentice Hall, Upper Saddle River, New Jersey, 663 p. 